\title{
THE PENSION SYSTEM REFORM IN GEORGIA: ACHIEVEMENTS AND CHALLENGES
}

\section{MIRZA KHIDASHELI}

Doctor of Business Administration,

Associate Professor

Kutaisi University, Georgia

mirza.khidasheli@unik.edu.ge

\section{NIKOLOZ CHIKHLADZE}

Doctor of Economic Sciences, Professor

Akaki Tsereteli State University, Professor of Kutaisi University, Academician of the Academy of Economic Sciences of Georgia, Georgia

nikoloz.chikhladze@atsu.edu.ge

\section{KEYWORDS: PENSION SYSTEM, PENSION REFORM, ACCUMULATIVE PENSION}

\section{INTRODUCTION}

The development of a pension system fulfilling the modern requirements, has always been the main flagship of the State's socio-economic policy and structural transformation. The question is relevant in the post-Soviet countries, including Georgia.

The Old Age Pension system of Georgia was established at an early stage of its post-independence period. Until the year 2004, the State has often been unable for months to pay to pensioners the already symbolic pensions. Since 2004, these kinds of problems have not arisen already for the State budget, but it remains difficult to achieve high rate of replacement of the existing pension system, which would provide a pension for people at retirement age, adequate to their earnings.

The improvement in the overall situation in developing countries had led to greater life expectancy. By 2050, expected growth of the population aged 65 and over will be $10-20 \%$. In addition, it should be noted that $80 \%$ of the elderly live in low-income countries. (Uglava, 2018)

It is because of growth in the average life expectancy, taking into account the migration and demographic conditions in society, there is an increasing pressure on the State budget caused by pension expenditure.

In 2018, the Government of Georgia developed and presented to Parliament the draft law on the accumulative pension system. According to the draft, participation in the accumulative pension scheme is compulsory for all employed persons, but the Pension Fund will be managed by LEPL - Pension Agency. Reform has two defined goals: 1. To ease the pressure on the State budget; 2 . To provide people at retirement age with pension at high replacement rate.

\section{THE ESSENCE AND PURPOSE OF THE PENSION SYSTEM}

As a rule, the need for pension reform is based on economic and demographic factors. With the growth of migra- tion flows, the links of people with society where they were brought up, where their parents lived is further weakened. In traditional society, these links were stronger; young and active able-bodied people lived in society, where they were brought up, and, accordingly, took care of their parents and needy members of society that they had known since they were born and had sympathized them. This has led to a conflict of interest between the productive portion of our society and its other representatives creating wealth.

With a deepening of globalization and urbanization processes, the the pension system is growing in importance, since, unlike traditional society, in modern society, people should take care of financial support for their old age.

The recent studies demonstrate that the level of financial literacy of society in the world does not exceed 35\%. (Klapper et al., 2015) It is important to note the myopia, as a factor, because people are unable to think and, consequently, to take care of their old age, and its financial security. Often, people chose to take risk, trying to consume as much as possible in working age in the hope that society will take care of them in in old age after their disability occurred. The aforementioned factors constitute a fact, which requires the State to take care of the pension system, its development, regulation, management and financial sustainability.

There are two crucial goals served by the pension system:

1. To alleviate poverty among older people;

2. To align the levels of consumption during the periods of retirement and working ability, in order to prevent a substantial decrease in the incomes of older persons, compared with incomes, which they received in working age.

The first of those is almost identical to the purposes of social programs, while the second one is considerably different from them, as it seeks to contribute to the living standard in retirement age.

The State seeks to achieve these goals through the various pension schemes, and sometimes, only by means of one scheme. There are pension systems, focusing more on pover- 
ty reduction, than on the alignment of the consumption levels (standard of living) in retirement and working ages. For example, the average pension in the United States is about 40 per cent of the average wage, and for persons with higher incomes, this parameter is only $20 \%$, while the pension of low-income persons is equal to their salary (income). (Biggs et al., 2009).

The achievement of the goals of the pension system is possible through various types of the pension schemes. The pension incomes mostly have two sources: taxes and pension contributions. In the case of taxes, the fiscal burden falls on the State budget, while in the second case- on pension funds.

\section{THE TYPES OF THE PENSION SYSTEM}

One of the most common ways to finance the Pension Fund is the "Pay as you go" system. In the case of this financial mechanism, the "contribution" paid by taxpayers directly goes to financing of pension payments from the State budget. In this system, the well-being of a person at retirement age is tied to the well-being of working people, and it is also called the "Defined benefit" scheme. An alternative method of financing is the "Defined contribution" scheme. In this case, expenses incurred by employees for pension purposes will be accumulated in the individual accounts and invested in various financial instruments. Beyond retirement age, pensions are paid out from the savings in these accounts. In the first case, the source of funding for pensions is the State budget. The "Defined benefit" mechanism can be implemented both on a monopoly basis, by a state agency, or through the private pension funds, in a competitive environment. In this case, payments and contributions to the Pension Fund are calculated in accordance with the percentage-based parameters of wages (for example, $n \%$ of salary).

In the case of the "Defined benefit" system, it is difficult to achieve a high replacement rate, since taxes are the main source of funding for this pension system. A significant increase in pensions and their approximation to income that is adequate to high standards of living lead to financial pressure on the State budget, which, in turn, affects the country's macroeconomic environment. Outside the "Defined contribution" mechanism, there remains a part of the self-employed persons, who do not take the initiative to join the funded pension system, as well as persons who are not actively involved in the labor force and have not been employed. Accordingly, these two mechanisms are often used as complementary instruments for people of retirement age in the struggle to reduce poverty and maintain the living standards.

Successful practice in achieving the goals of combating poverty and maintaining the living standards in retirement age is motivating seniors to remain of in their workplaces. Using this program, the State achieves two main goals:

- To reduce the pressure of the "Defined benefit" scheme on the State budget;
- To contribute to the process of poverty reduction and maintaining the living standards among people of retirement age.

This model has been successfully worked in Singapore, where it is implemented using the following instruments: special employment credit (SEC); employment assistance payment (EAP).

The beneficiary of special employment credit is an employer, who hires people aged over 65, on the basis of which he/she may receive compensation in the amount of up to $3 \%$ of the employee's salary. The EAP instrument requires the employer, if a person refused all the offered options on new employment, to pay to the latter compensation 3.5 times more than monthly salary. The model encourages the employer to renew the labor contract or seek alternative employment (Official webpage of the Mnistry of Labor of Singapore, 2016).

\section{THE PENSION SYSTEM IN GEORGIA: CHALLENGES AND PROSPECTS}

Citizens of Georgia - men at age 65 and women at age 60 , almost automatically become the beneficiaries of the state pension. The amount of the state pension for an old-age pensioner is GEL 180. (http://ssa.gov.ge) As at September 2018, the number of old-age pensioners is 741.7 thousand, which account for $20 \%$ of the country's population. In 2015, GEL 1303 million was needed to finance pensions for old-age pensioners, and by 2018, this amount will reach approximately GEL 1,605 million. (http://www.geostat.ge) Based on a demographic analysis, it is assumed that within 15 years, the older population will rise by $30 \%$, and by 2030 will reach 950 thousand people, which means that the older population will be a quarter of the country's total population. Such an increase in a short period of time will lead to significant demographic changes (http://www.economy.ge/?page=reforms\&s=15).

As at the year 2018, the number of old-age pensioners (741.7 thousand) makes up 33.5 per cent of the labour force (2215.2 thousand people). At present, the pension system as currently in force in Georgia relates to the "pay as you go" system, that is, to the "Defined benefit"-type system, according to which the "contribution", payable during tax remissions, goes directly to financing the pension payments from the State budget.

For in-depth analysis of the problem, let us consider the main indicators. Firstly, let us see what is the ratio of income tax payers and old-age pensioners. According to the data for 2018 , the ratio of old-age pensioners to the number of employees $(1,712.6$ thousand people) is $43 \%$. To obtain a more realistic picture, from the number of employees, it is desirable to subtract the number of "self-employed" persons in the agricultural sector (641.4 thousand people), which will lead to a reduction in the number of employed persons to 1071.2 thousand people. Since the State budget is the only source of fund- 


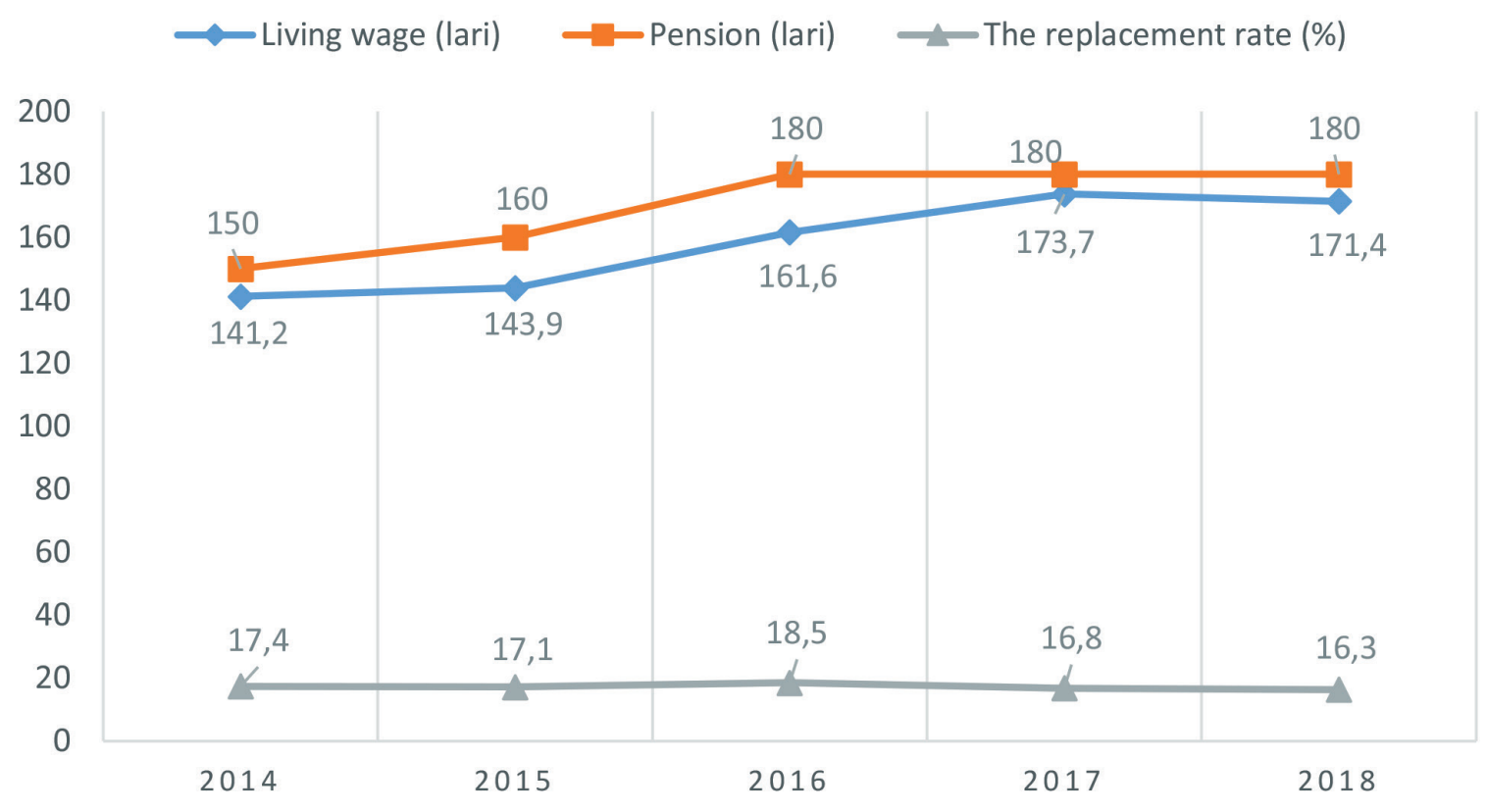

Figure 1

The evolution of the replacement rate in 2014-2018 (http://www.geostat.ge).

ing for this pension system, for a more accurate evaluation, this parameter should be reduced, based on the number of persons employed in the public sector (300 thousand people).

Consequently, for our research purposes, the number of employed persons is 771.2 thousand people, which is only by 29.5 thousand people more than the number of old-age pensioners, while the number of people receiving social pension, persons with disabilities, as well as persons receiving benefits for loss of breadwinner exceeds 800 thousand people. In the long term, against the background of a reduction in the number of people of working age, it will become increasingly difficult not only to increase pensions, but also to preserve the existing replacement rate, which is focused on overcoming poverty, and from the point of view of living standards, makes no substantial progress (see Fig. 1).

Without analyzing fiscal and other parameters, the considered social structure is absolutely sufficient to pose the question of the need to take steps to preserve the stability of the existing pension system and the living standards in retirement age.

\section{PENSION REFORM}

Since 2018, the law "On the accumulative pension" has entered into force in Georgia. The membership in the accumulative pension scheme is compulsory for all employers in terms of income received in the form of salaries. For making contributions to the pension fund, income from salary up to GEL 60,000 must be taxable. In the pension fund, the individual account of the person will be credited with:
- $2 \%$ of the wage, paid by employee;

- $2 \%$ of the wage, paid by employer;

- $2 \%$ of the wage, paid by the State.

The fund, formed from contributions, is managed by LEPP Pension Agency established by Georgia's Government Decision No 421 of August 15, 2018. The Agency maintains the records of employed and self-employed persons registered in the accumulative pension scheme, and creates an individual account for each registered member. A participant, on reaching retirement age, has the right to receive an amount equivalent to the value of the pension asset on his own individual pension account, in the form of a lump sum or program payment. If a participant dies before retirement age or prior to drawing up a pension program, the funds in his account will be transferred to his heir/heirs. The budget of the Pension Agency for the first three years will be funded entirely from the State budget. Over the next 10 years, the Agency's expenses should not exceed $1 \%$ of the pension assets, and after this period $-0.75 \%$. The Supervisory Board of the Agency is composed of four members:

a) Minister of Finance of Georgia;

b) Minister of Economy and Sustainable development of Georgia;

c) Minister of the Internally Displaced Persons from the Occupied Territories, Accomodation and Refugees of Georgia;

d) Chairman of Investment Committee.

The system aims to receive annual revenue that will be higher than the level of inflation. The higher the real profit generated by the system, the higher the replacement rate. Upon retirement, there will be two choices: an annuity, which implies a fixed amount of the pensioner's income in his/her 
lifetime, or redistribution of the accumulated amount in accordance with the age of the pensioner. The investment strategy will be based on the life-cycle approach. Along with investment regulation and diversification, a similar approach plays an important role in the context of protecting the pension fund from investment risk, and also contributes to the longterm profitability of the investment portfolio.

The life-cycle approach is as follows: based on the age of a citizen, the choice of his/her investment portfolio is made automatically. Young members of the system will be placed in the portfolio with the possibility of greater growth. Along with changes in age groups, savings will be moved into the balanced portfolios, in which stocks and fixed income instruments will be evenly redistributed. The life-cycle approach is especially important for countries with low levels of financial literacy and low incomes, as in most cases, citizens make the wrong choice regarding the long-term investments.

\section{CRITICAL ASPECTS OF REFORM}

The anti-capitalist mentality is a fact inherited by the post-Soviet states, and accordingly, building of institutions that are characteristic of a market economy calls for great effort. It is difficult to convince the general public of the need for funded pension, so that without any outside intervention, the private sector is able itself to ensure the development of a funded pension system.

Declaring, at the legislative level, to be compulsory participation in the scheme of funded pensions is an absolute need, but the same is not true of LEPL- Pension Agency, established for the management of the Pension Fund, which has the exclusive right to register and manage the accounts and assets of the Pension Fund. Nowhere in the state program is indicated on what criteria the establishment of an "independent" legal entity without any experience in managing financial funds was considered the best solution to the issue. Perhaps a better solution would be to entrust the role of the regulator and protector of the rights of pensioners to the State, which the National Bank could handle freely, and it would be better to entrust the accounting and management of pension accounts to the financial sector, as well as not to restrict citizens in choosing those they could entrust the accounting and management of their own pension account, and allow the pension funds for developing in a competitive environment.

A fundamental issue is the self-employed and the unemployed persons. According to the data of the second quarter of 2018, and this is not an exceptional case, the total number of employees does not even reach half of the labor force (see Fig. 2). Consequently, a system was created that would not give anything to most of the workforce at retirement age. They will still be the beneficiaries of old-age pensions, which, as the authors of the pension reform themselves note, cannot ensuring for them ageing with dignity.

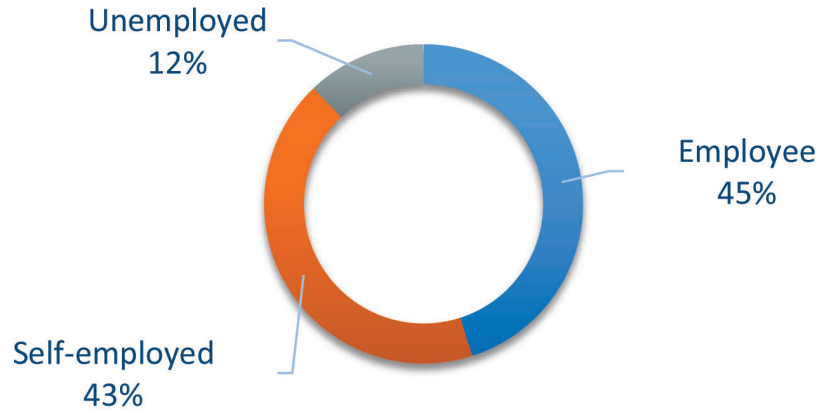

Diagram 2 Distribution of labor force, \%

If, in the structure of employment, the share of employees will not increase dramatically, the coverage ratio of the population in retirement, using the funded pension scheme, will not be enough to change the overall picture of the social status of persons of retirement age.

It is important to find out how much pension would come in retirement age to a person who receives an average salary. In order to simulate the situation, we take the average wage in the second quarter of 2018 (GEL 1023.8) as the baseline, and its growth rates and the inflation rate should be considered as the mutually balancing factors, as a result of which, the real baseline parameter remains unchanged. Capitalization of the pension funds varies from $5 \%$ to $8 \%$. (https://www. bloomberg.com/news/articles/2017-08-02/5-is-the-new-8for-reliable-returns-for-pension-funds). Let us assume an optimistic expectation, and take the $8 \%$ interest rate as a profit factor. According to the package of pension reform, proposed by the Government of Georgia, 40-year period of continuous service is the maximum period, during which a participant of the pension scheme continuously pays the pension contribution, and 18 years is the average length of a pension period. (https://matsne.gov.ge/ka/document/view/3839800)

Let us see, what the function of annuity gives us:

$1023,8 * 12 * 0,06 * \mathrm{FVIF}_{8 \%, 40}=737,1 * 259,1=109982,61$

Taking into account our assumptions, under conditions of 8-per cent capitalization, after 40-year period of continuous service, the person receiving the average salary will accumulate about GEL 110,000 in a pension account, which means that he/ she will receive a pension only from the funded pension account approximately GEL 509 per month. To this is added the state pension (GEL 180), resulting in a total pension of GEL 689.

The replacement rate, taking into account the state pension, makes up $67 \%$ and $50 \%$ without it. Both replacement rates correspond to the same parameters of the eurozone countries. However, the above calculations concern men under 25 years old, who will have uninterrupted length of service for the next 40 years, from the point of view of employment. Now, let us consider the case of men aged 45, who are only 20 years apart from retirement age:

$1023,8 * 12 * 0,06 * \mathrm{FVIF}_{8 \%, 20}=737,1 * 45,8=33759,2$ 
In case there is GEL 33,759.2 on the pension account, its owner, after retirement, will receive GEL 156.3 per month, which, taking into account the old-age pension, is GEL 336.3. In this case, the rate of replacement of wage by pension is $33 \%$, which coincides with similar indicators in Azerbaijan and Albania, and cannot be considered very successful.

\section{CONCLUSIONS}

The pension system of Georgia could not provide a high replacement rate, which is the main indicator for assessing the pension system. Accordingly, the existing pension system unambiguously needed urgent reform.

The proposed model of funded pension system does not contain convincing arguments that necessitate the establishment of LEPL- Pension Agency. The State could ensure the sustainability of the pension scheme in terms of regulation and control in such a way as not to monopolize this sector.
The study showed that reform is effective for young people, whose total duration of participation in the pension scheme is 40 years. In this case, the pension scheme provides a high replacement rate, which is not possible for persons whose participation in the pension scheme is not more than 20 years.

Depending on the existing structure of labor resources, the coverage ratio of the funded pension system remains low, since the participation of the self-employed and the unemployed persons in the pension scheme is of non-mandatory character. In addition, the State also does not provide for subsidizing the above-mentioned persons in the pension fund.

An obstacle remains the pressure of the pension system on the State budget. Despite the establishment of a funded pension system, the old-age pension still remains accessible to participants of the scheme, which, as noted by the authors of the reform, by 2030, will have a significant share in the structure of the State budget spending

\section{REFERENCES:}

1. Uglava D. (2018) The role of reforming the pension insurance system in the country's economic development. Dissertation for academic degree of Doctor of Business Administration. Ak. Tsereteli State University. p. 6. https://atsu.edu.ge/images/D.UglavasDisertacia.pdf

2. Klapper L., Lusardi A., Oudheusden P.V., (2015) Financial Literacy Around the World: insights from the standard \& poor's ratings services global financial literacy survey. https://responsiblefinanceforum.org/wp-content/uploads/2015/12/2015-Finlit_paper_17_F3_SINGLES.pdf

3. Biggs A., Tamborini Ch., (2009). A progressive Index for Social Security. Social Security. Office of Retirement and Disability Policy. Issue Paper \#2009-01. https://www.ssa.gov/policy/docs/issuepapers/ip2009-01.html

4. Official webpage of the Mnistry of Labor of Singapore (2016) https://www.mom.gov.sg/employment-practices/re-employment

5. Official webpage of LEPL - Social Service Agency (2018) http://ssa.gov.ge/

6. Official webpage of National Statistics Office of Georgia (2018) http://www.geostat.ge/

7. "Pension Reform of Georgia". Official webpage of the Mnistry of Economy and Sustainable Development (2018) http:// www.economy.ge/?page=reforms\&s=15

8. https://www.bloomberg.com/news/articles/2017-08-02/5-is-the-new-8-for-reliable-returns-for-pension-funds (2018)

9. "Pension Reform of Georgia". (2018) https://matsne.gov.ge/ka/document/view/3839800 


\section{THE PENSION SYSTEM REFORM IN GEORGIA: ACHIEVEMENTS AND CHALLENGES}

\section{MIRZA KHIDASHELI}

https://doi.org/10.35945/gb.2018.06.022

Doctor of Business Administration,

Associate Professor

Kutaisi University, Georgia

mirza.khidasheli@unik.edu.ge

\section{NIKOLOZ CHIKHLADZE}

Doctor of Economic Sciences, Professor

Akaki Tsereteli State University, Professor of Kutaisi University,

Academician of the Academy of Economic Sciences of Georgia, Georgia

nikoloz.chikhladze@atsu.edu.ge

\section{KEYWORDS: PENSION SYSTEM, PENSION REFORM, ACCUMULATIVE PENSION}

\section{SUMMARY}

The study showed that reform is effective for young people, whose total duration of participation in the pension scheme is 40 years. In this case, the pension scheme provides a high replacement rate, which is not possible for persons whose participation in the pension scheme is not more than
20 years. An obstacle remains the pressure of the pension system on the State budget. Despite the establishment of a funded pension system, the old-age pension still remains accessible to participants of the scheme, which, as noted by the authors of the reform, by 2030, will have a significant share in the structure of the State budget spending. 